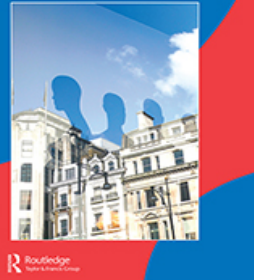

\title{
Irish civil society: rearranging the deckchairs on the Titanic? A case study of fighting Irish social security retrenchment
}

\section{Mary P. Murphy}

To cite this article: Mary P. Murphy (2016) Irish civil society: rearranging the deckchairs on the Titanic? A case study of fighting Irish social security retrenchment, Journal of Civil Society, 12:1, 17-32, DOI: 10.1080/17448689.2016.1117244

To link to this article: https://doi.org/10.1080/17448689.2016.1117244

曲 Published online: 08 Jan 2016.

Submit your article to this journal $\pi$

Џلll Article views: 109

Q View related articles $\square$

View Crossmark data ¿ 


\title{
Irish civil society: rearranging the deckchairs on the Titanic? A case study of fighting Irish social security retrenchment
}

\author{
MARY P. MURPHY \\ Department of Sociology, Maynooth University, Kildare, Ireland
}

\begin{abstract}
Examining the politics of Irish responses to crisis-related social security cuts gives insight into Irish agency and how crisis has shaped the contours of Irish civil society. Despite assertions of lack of protest, Irish retrenchment was resisted and sometimes partially defeated. Using political sociology frameworks to explore interactions between institutional, ideological and interest variables in three case studies of defending cuts enables analysis of resistance strategies. There are tensions when short-term defensive resistance strategies undermine or limit offensive political coalition-building that might offer greater long-term solidarity and more sustainable resistance to intensification of the neoliberal Irish welfare state.
\end{abstract}

\section{KEYWORDS}

Ireland; social security; austerity; defensive; offensive; retrenchment; politics of protest

\section{Introduction}

There is by now an extensive international scholarship examining global and national civil society in an age of crisis. Alongside social movement literature (Flesher Fominaya \& Cox, 2013) and feminist analysis (Walby, 2011), commentary in a 2011 special issue of the Journal of Civil Society 'Civil Society in an Age of Crisis' raised a number of important issues (Howell, 2011). Scholte (2011, p. 277), responding to Clark’s (2011) relatively pessimistic assessment of global civil society's response to crisis, acknowledges that the 'general lack of civil society mobilization in the face of the recent global financial and economic crisis ... is indeed striking and worrying'. We focus here on national mobilization of civil society to crisis, arguing that lessons from examination of the Irish context are useful for other national contexts.

White and Wood (in press) question the relationship between informal experiences of activism and more organized forms and ask how organizational forms of activism are informed by specific social and spatial temporalities, including crisis. They argue for more informed complex understandings of the organizational natures of activism in times of crisis so as to achieve better synergies between different types and patterns of activism and resistance. The aim of this article is to theoretically examine apparently disparate and isolated responses of different civil society campaigns in Ireland while also contributing to strengthening capacity to collectively respond to crisis.

Mainstream Irish and global media have welcomed what they perceive as Irish civil society's stoicism and maturity in the face crisis (as is the Financial Times, The Economist, 
The Wall Street Journal, Vanity Fair and the International Monetary Fund (Murphy, 2012)). Others described an 'extraordinarily moderate and passive society' (O'Brien, 2011, p. 15), or a 'passive' and 'demobilized' citizenry (Mair, 2010, p. 7). Such perceptions of passivity in Irish civil society are contested by many (Allen \& O’Boyle, 2013; Cannon \& Murphy, 2015; Carney, Scharf, Timonen, \& Conlon, 2014; Cox, 2012; Fraser, Murphy, \& Kelly, 2013; Hearne, 2015; Kirby \& Murphy, 2011; Murphy, 2012). Hearne’s (2015) analysis of Irish 'crisis' protests shows less passivity than often assumed and some successful 'single issue' roll back. He argues that protest mobilizations took place intermittently, often locally and across diverse themes. The most significant protest against austerity was a national mass turn out against water charges on 11 October 2014. Estimates for numbers marching varied with the more optimistic suggesting 200,000. This needs to be understood in the context of the Irish population of 4.6 million: the pro-rata UK figure would be 2.8 million (pop. 64.1 million). The scale and energy took the organizers, the media, and politicians by collective surprise; impact was immediate with the extension of relief for water charges beyond a small number of social welfare recipients to the wider population (McCarthy, 2014). This mobilization continued as the Right to Water campaign, which subsequently rebranded as Right to Change in an attempt to broaden its appeal to a wider progressive agenda.

This article explores the tensions within Irish civil society responses to a crisis that caused the most significant non-wartime collapse of a western economy and that was all the more spectacular given the degree to which Ireland's Celtic Tiger model had been championed as a success story of the neoliberal financial capitalist model. Emerging literature tends to stress the degree to which, in the notable absence of trade union leadership, progressive campaigns were often led by non-traditional civil society and radical left organizations (Carney et al., 2014). Hearne (2013b, p. 4) laments the failure of Irish social partnership and 'soft' nongovernmental organization (NGO) advocacy and contends that the more traditional civil society and trade union leadership relied on more passive forms of traditional lobbying and advocacy. He argues that mainstream Irish civil society is immersed in a dependent corporate state-society relationship. With what Hearne describes as their 'their traditional ally', the Labour Party, in government, NGOs were reluctant to engage in public mobilizations and 'potentially transformative tactics were lost by a civil society leadership that did not want to engage or unleash the popular resistance that radical change requires' (Hearne, 2013b, p. 4).

This ignores the many points of contestation where social policy retrenchment was resisted by civil society and in some cases successfully defeated. This article focuses not on the anti-austerity activity of the Irish left but on the responses to austerity of more traditional Irish civil society, commonly known as the community and voluntary sector (Daly, 2007). It argues that, with a relatively sophisticated understanding of Irish political culture, such groups were relatively successful in some instances at rolling back cuts or ensuring some key supports remained protected. Success here needs qualification: given the scale of Irish crisis budgets (30 billion euro fiscal consolidation over 6 years), small short-term victories can be likened to 'rearranging the deckchairs on the Titanic'; they need to be seen in the context of the overall intensification of neoliberalism. Nonetheless such victories contest assertions that civil society did not mobilize to any great extent against austerity politics during the crisis. The general argument, which may have application in other national contexts, is that accounts of resistance that focus only on visible 
'protest' run the risk of misdiagnosing the nature of protest and prescribing the wrong medicine for future action or alliance building.

I begin by introducing theoretical frameworks to assist in differentiating the role different change actors play in achieving both transformative and incremental change and to understand the interaction of three different variables, that is, institutions, interests, and ideas. The article then focuses on successful defensive contestation of three crisisrelated social security cuts: restricting eligibility to one-parent family payments; reductions in disability allowances; and changes to the universal Child Benefit (CB) income support. These are not representative, rather they are selected precisely because they contrast with significantly more retrenchment in Ireland's nearest neighbour, the UK. This contrast allows an appreciation of 'what might have been' in the absence of protest (albeit there has been significant UK protest which raises an equally important but unexplored question as to why certain retrenchments succeeded in the UK but not in Ireland). In these three case studies, we isolate key interactions between institutional, ideological, and interest variables that can explain why some forms of retrenchment were at least partially resisted and what kind of change agent strategies and tactics were pursued. The conclusion uses the framework offered by Wright (2013) to explore tensions between such successful resistance strategies and wider proactive engagement and political coalition building. We conclude that defensive strategies can undermine or limit more strategic narratives that, in the longer term, might have greater capacity to realize stronger solidarity and more sustainable resistance to the overall neoliberal direction of the Irish welfare state.

\section{Conceptual frameworks}

Some frameworks enable informed complex understandings of the organizational nature of activism in times of crisis, while others enable ways of understanding how to achieve synergies between different types or traditions of activism and resistance. Ellison (2000, para 1.2) understands the changing nature of citizenship as characterized by individualism and fragmentation into what he calls a series of 'temporary solidarities' which take the shape of 'a social politics characterized by "defensive" or "proactive" forms of engagement'. According to Ellison (2000, para 1.4), proactive engagement shapes new demands, ideas or practices and new forms of political action to reshape public agendas, including demands for new kinds of democracy, recognition of 'differences', or special status and new forms of 'solidarities'. Defensive engagement means citizens defending themselves against the erosion of their social rights created by the persistent and occasionally dramatic demands of rapid economic, social, and political change. This 'active defence' happens through interventions in the fragmented social politics of the public sphere and often in ways that undermine solidarity. Hay (2004) offers a three-dimensional framework to understand the process of contestation as the interaction of three variables, i.e. ideas, institutions and interests, and stresses the importance of avoiding privileging one of these factors over others.

Wright (2013, p. 21) identifies three strategic logics of transformation that characterize the history of anti-capitalist struggle. Ruptural or revolutionary transformations envision a sharp break with existing institutions and social structures through direct confrontation. Interstitial transformations seek to build new forms of social empowerment in capitalist society's niches and margins; these serve as both critique and evidence that alternative 
ways of working and living are possible. Symbiotic transformations involve strategies where the state and civil society simultaneously help to solve practical problems faced by dominant classes and elites through 'non-reformist reforms', that is, reforms that simultaneously make life better within the existing economic system but also expand the potential for future advances of democratic power. Wright argues that all three strategic logics have historically had a place within anti-capitalist politics and that, while it is intellectually easy to raise objections to each or even all of them, it is essential to take up the challenge of working across the three approaches 'to do things now that put us in the best position to do more later' (Wright, 2013, p. 22). This, for Wright, means a 'strategic orientation organized around the interplay of interstitial and symbiotic strategies, to create a trajectory of deepening socialist elements within the hybrid capitalist system, with perhaps periodic episodes involving elements of ruptural strategy which are a necessary trajectory of sustainable social empowerment and create space for the interplay of interstitial and symbiotic strategies' (Wright, 2013, p. 23).

\section{Irish crisis and impacts}

A reduction of $12 \%$ in GDP and $€ 30$ billion in fiscal consolidation are bound to have impacts. Early Irish crisis Budgets 2009-2010 were difficult for many people but progressive in their overall distributional impact, while later Budgets 2012-2015 were difficult but regressive. Keane et al. (2015, p. 12) sums up 'the net effect of Budgets 2009-2015 has been to squeeze incomes at all income levels, but most of all at the top and the bottom of the income distribution'.

There were generational patterns. In early budgets the working-age adult social welfare payments were reduced by $8 \%$ (from $€ 204$ to $€ 188$ ) while social welfare pensions remained protected at $€ 230$ for assistance-based pensions. During the crisis, social welfare was more than halved for those under 25 (from $€ 204$ to $€ 100$ ) and CB was reduced from $€ 166$ per month in 2010 to $€ 130$ per month in 2013 (with additional cuts to the higher payments for the $3 \mathrm{rd}+$ child). The combined impact of cuts and parental unemployment means child poverty doubled over the crisis. Social-welfare-dependent single families with children fared worst of all suffering cumulative annual cuts over the crisis.

Market impacts of the Great Recession have also been severe. Between 2007 and 2010 the numbers earning over $€ 100,000$ fell by almost $15 \%$, while the average income of those who were still earning over $€ 100,000$ fell by about $8 \%$ (Fitzgerald, 2014). Irish labour unit costs fell by $12.2 \%$ during the same period due to the imposition of wage cuts (especially in the public sector) and an increase in Irish labour productivity (Erne, 2013). Average annual disposable income fell from $€ 24,380$ to $€ 21,440$ between 2008 and 2011 (CSO, 2014). Unemployment rose from $6.4 \%$ in 2008 to nearly $15 \%$ in 2012 , but dropped to $9.8 \%$ by mid-2015. Long-term unemployment (over one year) rose from half of those unemployed in 2010 to $60 \%$ in 2012 and dropped to $58.4 \%$ in 2014; 60,000 are now unemployed for more than 4 years. Underemployment increased, male involuntary part-time employment doubled and the numbers of households with very low work intensity rose from $14.2 \%$ to $22.9 \%$ in the $2007-2011$ period (Watson \& Maître, 2013). Unemployment scarring is particularly salient among the working class. Joblessness remains closely correlated with low education qualifications and is a largely working-class experience. Ireland 
scores very high for the number of young people not in employment, education or training (Gonzalez Pandiella, 2013).

Poverty and inequality rose over the crisis but has not exceeded pre-Celtic Tiger levels (CSO, 2014). Watson and Maître (2013) find high levels of efficacy in Irish social transfers. Despite cuts, Irish welfare payments were relatively effective in cushioning people from the worst effects of rising unemployment and falling incomes. While social transfers reduced the pre-transfer poverty rate by $53 \%$ in 2004 , this rose to $71 \%$ by 2013 . Despite such resilience, deprivation rates still rose from $13.8 \%$ to $24.5 \%$ between 2008 and 2011 and rose up to $63 \%$ for lone parents (CSO, 2014). NESC (2013) outlines the significant social impact of the crisis: $10 \%$ of the people are estimated to experience food poverty; there is growing use of soup-kitchen-style food distribution and increased homelessness.

Over six years, the cumulative impact of austerity is deepening and the pressure of new charges (property tax, water charges, increased utilities, and transport and housing costs) became more difficult to sustain. Families with children are particularly hard pressed, especially those in housing mortgage arrears. Barry and Conroy (2013) show that women are more likely to be employed in the public sector, rely on public sector services and be in receipt of a social welfare payment; consequently reductions in social expenditure had gendered impacts. Generational consequences of the crisis are particularly acute. Emigration, unemployment, mortgage arrears and negative equity affect young people and younger households more than older households. There is every likelihood of significant scarring for what has become known as 'a lost generation'.

The overall character of policy and institutions remains consistent, but there has been an intensification of the neoliberal model. While there have been tax increases, Ireland remains a low-tax regime with growth in privatization of public services, user charges, dualization in the labour market, and a sanctions-driven activation regime, and declines in social protection, investment in health, education, housing, social, care, local, and community development services. Clearly there is much to protest about.

\section{Social security cuts}

Ellison (2000) argues that different groups, regardless of their possession of specific resources, adopt both offensive and defensive strategies and that one cannot equate proactive forms of engagement with economic strength and defensive forms with economic weakness. Rather, groups choose to use their power resources in different ways depending on the issue in question. Defensive engagement means citizens defending themselves against the erosion of their social rights (Ellison, 2000). Such protest is more likely to be organized defensively around social divisions already shaped by existing policy discourses, for example, welfare provision. Proactive forms of protest can push beyond these discursive parameters, for example, framing new debates about ecological sustainability or new forms of democracy. While there are numerous examples of both offensive and proactive Irish agency, for the purposes of this exploration we focus here only on examples of defensive campaigns found in Irish social security policy. These three examples relate to lone parent cuts, $\mathrm{CB}$ cuts and disability allowance cuts. These are but three specific cuts in the context of a 30 billion euro fiscal consolidation, the vast majority of which was not rolled back in any way. 


\section{One parent family payment campaign}

Early in the crisis the Department of Social Protection (DSP, 2010) proposed a single social-assistance payment for people of working age (SWAP). Budget 2011 introduced two key structural reforms to an existing One Parent Family Payment (OFP) for which lone parents are eligible up to age 18 of youngest child and up to age 21 if the youngest child is in full-time education. Firstly, Budget 2011 declared that eligibility for the payment was restricted to lone parents with children younger than 14, while a Budget 2012 decision further reduced age eligibility to age 7. Secondly, a higher earnings disregard for lone parents-originally given in recognition of high childcare costs-was also reduced with phased reductions reducing earnings disregards by $60 \%$ by 2016 , levelling it down in line with Jobseeker's Allowance. These reforms meant extending jobseeker activation conditions to former OFP recipients, so that they would be required to be capable of, available for, and genuinely seek full-time employment. Many lone parents of young children manage work-life balance, and avoid high childcare costs, by working during school hours. Job search criteria exclude such working patterns. Lone parents could be ineligible for income support if they wanted to work part-time, and the proposed reforms could result in lone parents, giving up part-time work, or being denied income support for refusing to take up offers of full-time work.

In response to these changes, the 'Seven is too Young' campaign was fronted by OPEN (One Parent Exchange Network, an existing national, self-organized network of local lone parent groups), and fought the introduction of withdrawal of the OFP from lone parents whose youngest child was age seven or over. The campaign material (OPEN, 2012) argued, 'This unnecessary reform is untimely, ungainly and ill-fitting a government which has both international and national obligations to reduce poverty, look after children and protect the most vulnerable.' OPEN managed to secure crowd-sourced funding for a significant bus-stop advertising campaign and worked with other groups, including National Women's Council of Ireland (NWCI) and Children's Rights Alliance (CRA). They also collaborated with Single Parents Acting for Our Kids (SPARK), a more militant group of single parents who organized a parallel 2013 protest, engaged in a Facebook campaign and mobilized a more politically targeted campaign highlighting the role of the Labour Party in the proposed cuts.

As the date for reduction of the age threshold approached, a climbdown appeared in the form of new transitional arrangements announced in May 2013 and applied to lone parents whose youngest child is over the age of 7 (and therefore no longer eligible for OFP) but under age 14. DSP announced a mitigating 'Jobseeker Transitional' arrangement for this group ( $40 \%$ of OFP recipients), temporarily exempting them from jobseeker conditionality requirements. They will not be required to seek full-time work, and can continue a part-time work pattern of more than three days a week (qualifying for a reduced Jobseeker payment subject to means). When their youngest child reaches age 14, these parents will transfer to full conditionality under the main Jobseeker scheme. This was an important climbdown and a partial victory for the 'Seven is too Young' campaign. It was also a potentially subversive policy outcome, where policy innovation and policy entrepreneurs created a new layering mechanism, JobSeekers Transition (JST), which has potential to open up space for other reforms, including individualization of social security. In November 2014, in a further roll back of cuts, DSP announced they 
would not implement the final $€ 30$ of cuts in earned income disregards for OFP, subsequently in October 2015 they announced a restoration of $€ 30$ in earned income disregards for JST.

\section{Disability cuts campaign}

People with disabilities are organized in a variety of diverse ways and CSO's many of which had presence in Irish anti-austerity campaigns. Budget 2012 saw controversial cuts in social-assistance entitlements related to disability and caring. Measures announced in Budget 2012 provided, from January 2012, the extension of the minimum age of entitlement for Disability Allowance (DA) from 16 years to 18 years for new claimants. Further, from April 2012, for new claimants aged 18-24, the rates of payment for DA would align with Jobseeker's Allowance rates, that is, €100 a week for people aged 18-21 and $€ 144$ a week for people aged 22-24 (reduced from $€ 188$ per week). The significant cut of $€ 4576$ a year for people aged 18-21, and €2288 a year for people aged 22-24 would impact on 11,869 persons, almost $12 \%$ of all recipients of DA.

Political response was strong and immediate. The National Disability Federation (2012) and Inclusion Ireland (2011) made strong public protest with the latter arguing that 'such thinking shows a total lack of understanding of the support needs of people with a disability, disregards the additional costs associated with disability, and appears to roll back on the principle of recognition of disability under the Equal Status Act'. The Dublin Branch of Down Syndrome Ireland organized a petition against the change. The public responded to the campaign of a 16-year-old Cork girl Joanne O’Riordan, who suffers from Tetra-amelia syndrome, a rare condition characterized by the absence of limbs. Having secured a previous live TV commitment from the future Taoiseach (Prime Minister) ahead of the 2011 general election that if elected he would not reduce disability funding, she immediately rebuked him for introducing the Budget 2012 disability cuts. In the context of strong public support, government changed its mind (Boland, 2012). On 30 December 2011, under cover of the Christmas break and within three weeks of the budget announcement, Taoiseach (Prime Minister) Enda Kenny referred the cut to the National Advisory Group on Tax and Social Welfare, which has been established by the Minister for Social Protection in June 2011 (Journal, 2011). The Advisory Group first reported in 2013 (DSP, 2013) and argued that more evidence was needed to support the rationale for age-related reductions for DA recipients. A subsequent unpublished 2014 report recommended no such alignment. The cut was never implemented. The political agency of carers was recognized when Budget 2016 fully reversed 2012 cuts to a respite care grant.

Responses to disability cuts appeared largely left to disability activists and NGOs. The starkest illustration of sectoral responses was the 'Black Thursday' national protest by profoundly disabled disability activists reacting to cuts of $€ 10$ million or over 430,000 hours of personal assistance from the Personal Assistance Service budget announced on 30 August 2012. The Center for Independent Living (CIL, a nationwide organization run by people with disabilities which introduced Personal Assistance Services to Ireland 20 years ago) argued the cut would make people with disabilities 'prisoners in our own homes'. The CIL organized a powerful overnight picket of the Irish parliament by people with disabilities and their personal assistants. This captured public attention and proved a major political embarrassment. Government quickly relented but protesters offensively and 
defiantly maintained the vigil and creatively used the opportunity to proactively refocus the political debate to press for a rights-based response and for the government to immediately ratify the UN Convention on the Rights of People with Disabilities (Irish Times, 2012).

\section{The defence of universal CB campaign}

Ireland's austerity regime has also seen severe cuts in child income supports. Budget 2009 announced a phased withdrawal of universal CB income support for children aged 18. A Universal Early Childcare Supplement for children under age six was halved, then abolished at the end of 2009 and a compensatory universal (school) year of free half-time pre-school Early Childhood Care and Education (ECCE) was introduced in 2010. CB was cut by a further $10 \%$ in 2010 . Up to this point, social-welfare-dependent families had been protected from the impact of $\mathrm{CB}$ cuts with increases in other child-related entitlements. But from 2011, when CB rates were cut by a further $7 \%$, the poorest families were not compensated or protected. Budget 2012 announced the phasing out of higher CB rates for larger families and introduced cuts in mean-tested child income supports. Further CB cuts were implemented in 2013, so that cumulatively, rates have been cut by $22 \%$ for smaller families, and by a third for larger families. Further cuts in means-tested child income supports were implemented in 2013. Income support for back-to-school costs was withdrawn for pre-school children, and the allowance was cut by $18-25 \%$. Income supports for back-to-school costs were further reduced by $20-33 \%$ in subsequent budgets.

Since the beginning of the current economic downturn, new austerity measures across the EU have meant cutbacks in pensions and health care and a move away from universal CB to an emphasis on means-tested payments (Heise \& Leirse, 2011). While the range of cuts to Irish CB and other child income supports outlined above was significant, it was also the case that Ireland survived six austerity budgets without means-testing or taxing the universal $\mathrm{CB}$ payment. This can be contrasted to the British experience where $\mathrm{CB}$ is now income-tested. The universal nature of the payment was maintained in the context of strong pressure from various quarters, including the formidable Troika (International Monetary Fund, European Central Bank and European Commission) who supervised Ireland's $€ 85$ billion bail-out. Universality was successfully defended by a range of groups, some coordinated and some not.

In the period leading up to and after Budget 2009, there was intense speculation that CB would be a major plank of austerity packages. Initial media debate was promoted by a 2009 report from the Government-commissioned examination of Public Service Numbers and Expenditure Programmes, known as the McCarthy Report, (McCarthy, 2009), which recommended an across-the-board cut in CB rates and a 2009 Report of the Commission on Taxation (2009), which recommended that CB should be taxed. An alliance of groups formed to fight for $\mathrm{CB}$ to be retained as a universal payment and maintained at present levels. Both the NWCI and the CRA were in the forefront of opposing any cuts in $\mathrm{CB}$ (NWCI, 2009a). An NWCI (2009a) briefing paper championed CB as a universal payment that directly supports mothers and is often the only direct payment to mothers, assists childcare costs for working mothers and acts as a payment for those who care in the home. An NWCI membership survey showed CB to be a critical part of family income with $45 \%$ attesting cuts in CB would be a 'financial disaster' for their 
families (NWCI, 2009b). The CRA (2009) pre-budget submission to government strongly opposed any cuts, tax or means-testing of $\mathrm{CB}$ and framed $\mathrm{CB}$ as a valued child-centred payment which supported universalism and horizontal distribution. It pointed directly to the potential electoral fall-out: 'taxing or means-testing CB would be deeply and politically unpopular' (CRA, 2009, p. 6). The 2009 Pre-Budget Dail (Irish Parliament) Debates (1 December 2009) show government referencing the McCarthy (2009) and Commission on Taxation (2009) alongside NWCI and CRA submissions. Clearly NGOs had some political impact.

Post-election 2011 a new Labour Party Minister for Social Protection established the Advisory Group on Tax and Social Welfare, mentioned above. This first met in June 2011 and by November 2011 its interim report argued that short-term cuts in Budget 2012 would militate against longer term reforms to the child income support arrangements (DSP, 2011). It submitted its first report, Child and Family Income Support, on 27 March 2012 and argued for retention of a universal CB in respect of all children alongside a better targeting of child income support payments through a two-tier Child Income Support payment which would result in a reduction in the level of the universal payment but with compensation delivered through the targeted tier of the payment to those within the lower to the middle of the income distribution (DSP, 2012). They argued this would ease the transition from welfare to work and reach more families than the existing in-work Family Income Supplement (which it would effectively replace).

The report was complex and difficult to decipher. It was launched into an increasingly hostile political environment, and it was negatively received by civil society, women's groups, media, and the public. The 'Protest against Cuts to CB' (PACUB) was founded by a group of mothers working in the home who had been fighting to protect $\mathrm{CB}$ since the April 2008 initial cuts were made to the Early Childcare Supplement. They organized protests and a 2012 petition with 28,000 signatures and worked successfully with the NWCI to launch a successful media campaign against taxing or means-testing CB (Irish Independent, 2011). Media also took up the campaign and the electoral threat was enough to put paid to any reform agenda that sought to means test or tax CB. In October 2014 the Tánaiste and Minister for Social Protection confirmed government's commitment to maintain a universal $\mathrm{CB}$ and increased $\mathrm{CB}$ by 5 euros per child in Budgets 2015 and 2016 even though a Barnardos child poverty campaign argues the money might be better targeted at child poverty (Finlay, 2015). This can be compared to the UK, where there has also been very strong opposition to the government's proposal to reduce $\mathrm{CB}$ for middle- and high-income earners as part of an austerity package. In 2010 the rate of CB in the UK was frozen for 3 years. From January 2013, households where one parent earns more than 50,000 pounds will have restricted access to CBs.

\section{What can we learn about the politics of reform?}

Using Hay's framework (2004), Table 1 outlines the key institutional, interests and ideological features of the three defensive social security case studies. Civil society is a contested concept; the approach taken here is to understand that the distinctive form civil society takes reflects the institutional logic of capitalist arrangements in any one country (Roginsky \& Shortall, 2009). Roseneil and Williams (2004) argue that social movements are profoundly shaped by the policy direction of the governments they seek 
Table 1. Summary of institutions, interests and ideologies.

\begin{tabular}{|c|c|c|c|}
\hline Campaign & $\begin{array}{l}\text { One parent family payment } \\
\text { restricted to youngest child } \\
\text { under seven }\end{array}$ & $\begin{array}{l}\text { Disability allowance and personal } \\
\text { services assistant budgets }\end{array}$ & $\begin{array}{l}\text { Universality of Child } \\
\text { Benefit (CB) income } \\
\text { support }\end{array}$ \\
\hline $\begin{array}{l}\text { Institutions } \\
\text { Where protest occurred } \\
\text { and mechanisms used }\end{array}$ & $\begin{array}{l}\text { - } \text { - Facebook } \\
\text { - 'Seven is too Young' } \\
\text { public poster campaign } \\
\text { - Direct lobbying of } \\
\text { constituency offices } \\
\text { - SPARK protest 'buggy' } \\
\text { march } \\
\text { - Direct interaction with } \\
\text { - } \text { party politics, lobby days } \\
\text { - Confrontational protest }\end{array}$ & 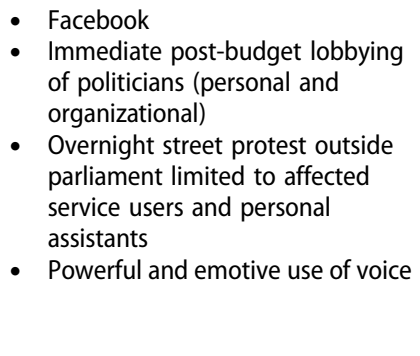 & $\begin{array}{l}\text { - } \text { Facebook } \\
\text { - } 28,000 \text {-signature } \\
\text { PACUB petition } \\
\text { - Pre-budget } \\
\text { submissions } \\
\text { - } \text { Alliance and } \\
\text { coalition building } \\
\text { - Response to } \\
\text { expert group } \\
\text { report } \\
\text { - Media }\end{array}$ \\
\hline $\begin{array}{l}\text { Interests and actors } \\
\text { Who worked in specific } \\
\text { alliances }\end{array}$ & $\begin{array}{l}\text { OPEN, CRA, } \\
\text { Barnardos, SPARK } \\
\text { NWCI }\end{array}$ & DFI, II, CIL, Down Syndrome Ireland & NWCI, CRA, PACUB \\
\hline $\begin{array}{l}\text { Ideologies/Values } \\
\text { Major frames }\end{array}$ & $\begin{array}{l}\text { - } \text { Mother/child } \\
\text { - Parenting } \\
\text { - Want to work but not until } \\
\text { - } \text { adequate childcare } \\
\text { - Protect vulnerable }\end{array}$ & $\begin{array}{l}\text { - Right to participate } \\
\text { - Voice and dignity } \\
\text { - } \text { Right to work } \\
\text { - International disability rights } \\
\text { - Protect vulnerable }\end{array}$ & $\begin{array}{l}\text { - } \text { Mother and child } \\
\text { - Universality } \\
\text { - Parenting values } \\
\text { - Protect vulnerable }\end{array}$ \\
\hline
\end{tabular}

to influence. Each state actively reframes civil society's political claims, policy demands and public values. Irish NGOs operate in the context of Irish political culture, ideology and institutions and these three cases need to analysed and understood in this context. Adshead and Tonge (2009) identify Ireland's peripheral location, conservative and rural culture, Catholic deference and a weak left as key factors influencing the political culture of Irish civil society. O'Brien (2011) points to the 'weak infrastructure of dissent' in a historically legitimate Irish state caused by a broader post-colonial tendency to accept authority. Others point to the nature of education and an absence of citizenship education, and others to the 'safety valve' of emigration as explanations for civil society passivity. More find explanation in the 1920s civil war and an absence of class cleavage in Irish society leading to the under-formation of the Irish political left (Murphy, 2012).

The nature of institutions also informs attitudes to protest and may explain the predominance of defensive-style protest and the lack of a more strategic and long-term offensive orientation. Political culture interfaces with a multi-seat proportional electoral system which perpetuates clientalism, localism, and personalism. The corporatist nature of the Irish state has also the capacity to co-opt or silence civil society. Key organizations have participated in a long social partnership with the state which has left a legacy of interdependence between the state and civil society (Murphy, 2012). Over decades, organizations have grown comfortable and skilled in a particular style of campaigning and enjoyed a significant level of access, even if over time the same level of access sits alongside declining influence.

In terms of institutions it is clear that the protests are oriented towards the political system using largely traditional methods: pre-budget submissions, media campaigns, lobbying and stunts (small, focused, and picket-like protests); there are few significant moments of militancy, street marches, or mobilizations. This approach is consistent 
with a number of successful Irish protests, for example, the over-70's defence of medical cards in 2008 and demonstrations against cut backs to special needs education assistants in 2010 and cuts to designated disadvantaged schools in 2011. To some degree the small size of the state, the very local and personalized nature of political culture and the ease of access to political institutions, including the political elite, means the political system is accessible to wider groups, thus mitigating the 'need' for more visible expressions of anger but also making protest itself less visible. While there is use of social media, with Twitter and Facebook dominant alongside new web-based lobbying technologies, there is also a reliance on traditional methods. With notable exceptions, such as a carnival-like anti-austerity parade 'Spectacle of Defiance', there is relatively little innovation, creativity, or use of arts or culture.

In terms of interests or actors, much of the momentum and orientation is from preexisting sectoral and self-organized single-issue NGOs who act as the 'voice' of those experiencing the cuts. There are various levels of mediation of people directly impacted by cuts, and NGOs often appear flexible enough to incorporate or work alongside other forms of protest emerging from left political mobilization (in the case of SPARK and OPEN collaborating in parallel and complementary campaigns, and in the case of PACUB and NWCI working together). There is a resistance to what is perceived as 'political-hijacking' or of appearing overly political in analysis. This may be related to tangible fear that overt political protest would have implications for statutory funding and relationships (Harvey, 2014), with some evidence that a number of groups felt inhibited from or suppressed protesting as they either feared or experienced a direct loss of funding or policy access subsequent to protest activity. This may in part explain an absence of significant cross solidarity between wider groups protesting retrenchments. It is also difficult to maintain the profile of single equality issues (gender and disability) in larger more overtly anti-austerity campaigns, and there is the direct opportunity cost of investing in wider campaigns in the context of diminishing human and financial resources.

Finally in terms of ideology or values, the macro narrative is protecting the vulnerable. Budget distributional analysis evidences the real vulnerability of the groups being defended. Images are striking-small protests of women with children in pushchairs or people with disabilities and wheelchairs outside the high railings which enclose the national parliament. However, vulnerability exists alongside an offensive rights discourse in disability campaigns and offensive demands for investment in childcare in gendered campaigns. The tendency is for vulnerable people to show their vulnerability, for women's groups in particular to frame the protest around children's vulnerability and for disability groups to self-organize to protect welfare and advance rights. There is no macro narrative focusing on capitalism or the vagaries of the neoliberal regime and specifically there is no dominant 'anti' austerity, capitalist or 'neoliberal' framing. This does not necessarily imply that such groups support fiscal consolidation; rather, the core message is framed around 'vulnerability' as a compass for managing fiscal consolidation. Groups appear conscious that appeals to vulnerability are more likely to work politically but also reinforce such values over alternative values such as equality. The call is clearly on existing values, and with the exception of 'rights' and 'investment', there are few attempts to create a narrative around new values. Defensive strategies tend not to challenge but reinforce popular opinion. This implies a break with pre-crisis strategies of such groups who were engaged in 
asymmetric partnership arrangements with the state but perhaps more creatively interplayed with public opinion (Larragy, 2014).

Mahoney and Thelen (2010) use the term 'symbiotic change agents' to identify those who carry out activities that work within status quo arrangements, while also depending on those arrangements for their own survival. 'Parasitic symbionts' survive by propping up an unsustainable environment and leave themselves exposed. This can happen in defensive strategies which play into conservative Irish political culture and values where traditional left-right clusters are less evident (Hardiman, McCashin, \& Payne, 2004). Defensive strategies can create discourses that play into dominant values that the same civil society groups may otherwise and historically have been attempting to challenge, and this is nearer the experience of parasitic symbionts. For example, precrisis lone parent proposals appear dominated by a social democratic approach to paid employment (evident in calls for a childcare investment package). Such ideology, however, co-exists with a conservative ideology that seeks to protect mothers in the home, to reinforce the role of mother in the home and parenting. The 'Seven is too Young' campaign clearly called for investment in childcare, but the overall frame of the campaign also reinforced the mothers as 'vulnerable' and played into the considerable Irish ambiguity surrounding the issue of mothering, welfare and paid work. The CB campaign may have done likewise. Key informants suggest that they were very aware of such tensions and attempted to keep more offensive values on the agenda whilst pragmatically appealing to Irish concerns about the key vulnerabilities of mothers caring for young children.

To what degree might such lessons bear relevance for understandings of responses to crisis in Greece, Spain, Portugal, and elsewhere? Clearly, national, historical, ideological, institutional, and interest formation patterns are important. However, other more immediate differentiating factors are worth noting. Motivation to protest may not have been as strong as in other crisis countries where key indicators such as unemployment, poverty and evictions were significantly higher than in Ireland and, as discussed earlier, the Irish welfare state, despite cuts, has proved resilient and effective (Cannon \& Murphy, 2015). Government and elites also worked effectively to maintain a narrative of 'no alternatives'. While budgets were largely regressive to some degree, cuts did impact on all income deciles, with the top $10 \%$ experiencing the greatest proportional decline in income. Emigration also proved a type of safety valve.

\section{Conclusion}

This article focused on specific points of contestation where social policy retrenchment was resisted and specific reform proposals at least partially defeated. In part motivated by the desire to celebrate agency and contest the dominant narrative asserting Irish responses to austerity as passive and devoid of protest, it also sought to critically interrogate such contestation and explore the limitations and consequences (intended and unintended) of such campaigns. By examining the interaction of three variables-institutions, interests and ideas - the analysis drew out key patterns across three different types of social security contestation. It pointed to key features of defensive resistance, including defensive stand-alone campaigns, limited alliance building, sectoral-specific strategies particularly 
fronted by those experiencing cuts, manipulation of underlying ambiguities concerning liberal, social democratic and conservative value systems, and electoral threats.

While valuable in the short term, there was little evidence that these successful defensive resistance strategies contributed to wider political coalition-building and broader offensive anti-austerity strategies. There is, as Urry (2000) and Ellison (2000) suggest, a more fractured and indeterminate quality of citizen participation and more complex patterns of engagement. The examples given show a visible lack of solidarity; public images are of sectoral defences 'circling the wagons' to defend their social provision and are at times suggestive of even parasitic forms of symbiotic engagement. This can contribute to an absence of certain forms of social solidarity in Ireland. Allen (2012) concludes that elites conjure up circumstances which fragment society and limit the possibility of social solidarity, while Carney et al. (2014) find that family solidarity trumps social or community-based solidarity. Solidarity is further undermined by a 'fragmented imagination' where we are collectively unable to connect different dimensions of crisis, in part because differing parts of political economy are reported separately and remain unconnected (Preston \& Silke, 2011). The lack of a macro narrative may undermine more strategic narratives that, in the longer term, might have a greater capacity to realize a more sustainable resistance to the overall neoliberal direction of the Irish welfare state. Irish NGOs do reflect on and are aware of these more hidden consequences. However there is also a danger inherent in rejecting these attempts to defend social provision and to promote an either/or scenario for protest, as some calls from those in more overt proactive engagement or revolutionary protest scenarios have tended to do (Hearne, 2013b). The challenge as framed by Wright (2013) is to recognize the fragmented, complex, and diverse nature of social politics and the public sphere and to mobilize across this complexity.

The wide diversity of institutional forms seen in Irish responses to austerity reflects institutional pluralism and can be seen as a strength rather than as a weakness. Proactive offensive coalition-building strategies need to work with and alongside defensive engagement strategies to develop strategic narratives that, in the longer term, can maintain solidarity and more sustainable resistance to the overall neoliberal direction of the Irish welfare state. When mounting defensive strategies, the challenge for civil society is to avoid parasitic symbiont outcomes and to look for reforms that simultaneously make life better within the existing economic system but also expand the potential for future advances of democratic power. This includes defending state services as crucial battlegrounds in combating financialization (McCabe, 2013), 'building alliances and coalitions between trade union, community and civil society organizations and taking action which is essential to broaden and strengthen support' (Whitfield, 2012, p. 117). McCabe (2013) argues that there have been some attempts by Irish actors to accommodate institutional pluralism and heterogeneity in civil society responses to crisis. Other recent evidence of 'breaking the mould' can be seen in global development agencies refocusing efforts to campaign about domestic and global inequalities. Likewise the success of the water charge mobilization discussed in this article's introduction has prompted many to think again about the possibilities of wider mobilization and suggests a level of anger behind largely defensive protests. The origin of the often local water campaigns has been explained as an outcome of structural strain or 'the straw that broke the camel's back'. Hearne relates it to discontent with not only austerity but also democracy. Hourican (2015) 
argues that the eruption of such an offensive style of campaign was not surprising given the extent of austerity and that its timing might be explained by the particular issue being particularly sensitive in a post-colonial political culture where 'local' and 'community' holds a dominant place in the value system. The local installation of water pipes in neighbourhood streets brought austerity 'home'.

The scale of the water protests has been described as exceptional but such a scale is not unique in Irish protest. The 750,000 that participated in the tax march of 1979, and more recent protests of 100,000 (against the Iraq War in 2003, labour market exploitation of migrants in 2005, and anti-austerity in 2010) all bear witness to significant Irish capacity for protest.

Against Wright's (2013) framework, the case studies explored rarely sought wider social transformation. Their strategies are clearly symbiotic rather than interstitial or ruptural. However it can be argued that even their limited success can prompt and inspire more agency and feed into other transformational strategies. As Clark (2011) argued, civil society must be conscious of the degree to which crisis moulds its own contours and of how it has to consciously maintain capacity to collaborate across defensive and offensive strategies and very different mobilizing traditions.

\section{Disclosure statement}

No potential conflict of interest was reported by the author.

\section{References}

Adshead, M., \& Tonge, J. (2009). Politics in Ireland convergence and divergence in a two policy Island. Basingstoke: Palgrave Macmillan.

Allen, K. (2012). The model pupil who faked the test: Social policy in the Irish crisis. Critical Social Policy, 32(3), 422-439.

Allen, K., \& O’Boyle, B. (2013). Austerity Ireland. London: Pluto Press.

Barry, U., \& Conroy, P. (2013). Ireland in crisis 2008-2012: Women, austerity and inequality. In J. Rubery \& M. Karamessini (Eds.), Women and austerity-the economic crisis and the future for gender equality (pp. 186-206). London: Routledge.

Boland, R. (2012, June 1). Joanne O’Riordan: 'People used to say: She's the one with no arms or legs. They're nicer now'. The Irish Times. Retrieved June 1, 2012

Cannon, B., \& Murphy, M. P. (2015). Where are the pots and pans? Collective responses in Ireland to neoliberalization in a time of crisis: Learning from Latin America. Irish Political Studies, 30(1), $1-19$.

Carney, G. M., Scharf, T., Timonen, V., \& Conlon, C. (2014). 'Blessed are the young, for they shall inherit the national debt': Solidarity between generations in the Irish crisis. Critical Social Policy, 34(3), 312-332.

Central Statistics Office (CSO). (2014). SILC 2013. Dublin: C.S.O.

Children's Rights Alliance (CRA). (2009). Pre-budget submission to the department of social and family affairs. Dublin: CRA.

Clark, J. (2011). Civil society in the age of crisis. Journal of Civil Society, 7(3), 241-263.

Commission on Taxation. (2009). Report of commission on taxation. Dublin: Stationery Office.

Cox, L. (2012). Challenging austerity in Ireland: Community and movement responses. Concept: The journal of contemporary community education practice theory, 3(2), 1-6.

Dail Debates. (2009, December 1). Child benefit motion. Retrieved from www.kildarestreet.com/ debates. 
Daly, S. (2007). Mapping civil society in the Republic of Ireland. Community Development Journal, 43(2), 157-176.

Department of Social Protection (DSP). (2010). Report on the desirability and feasibility of introducing a single social assistance payment for people of working age. Dublin: DSP.

Department of Social Protection (DSP). (2011). Advisory group on tax and social welfare interim report. Dublin: DSP.

Department of Social Protection (DSP). (2012). Advisory group on tax and social welfare 2013 first report: Review of child income supports. Dublin: DSP.

Department of Social Protection (DSP). (2013). Advisory group on tax and social welfare 2013 second report: Review of budget proposals regarding disability allowance and domiciliary care allowance. Dublin: DSP.

Disability Federation Ireland. (2012). 2012 budget analysis. Retreived from http://www.disabilityfederation.ie/index.php? uniqueID $=10490$

Ellison, N. (2000). Proactive and defensive engagement: Social citizenship in a changing public sphere. Sociological Research Online, 5(3). Retreived from http://www.socresonline.org.uk/5/3/ ellison.html

Erne, R. (2013). Let's accept a smaller slice of a shrinking cake. The Irish Congress of Trade Unions and Irish public sector unions in crisis. Transfer: European Review of Labour and Research, 19(3), $1-40$.

Finlay, F. (2015). Viewpoint: We need to spend more money giving all children a better start. Retreived October 28, 2015, from http://www.irishexaminer.com/viewpoints/columnists/ fergus-finlay/we-need-to-spend-more-money-giving-all-children-a-better-start-355072.html

Fitzgerald, J. (2014, January 16). Jobs for unemployed is key to reducing risk of poverty. Irish Times Opinion.

Flesher Fominaya, C., \& Cox, L. (Eds.). (2013). Understanding European movements: New social movements, global justice struggles, anti-austerity protest. Abingdon: Routledge.

Fraser, A., Murphy, E., \& Kelly, S. (2013). Deepening neoliberalism via austerity and reform: The case of Ireland. Human Geography, 6(2), 38-53.

Gonzalez Pandiella, A. (2013). Getting Irish youth on track economics (Department Working Papers No 1101) (Eco/Wkp (2013) 93). Paris: OECD.

Hardiman, N., McCashin, A., \& Payne, D. (2004). Understanding Irish attitudes to poverty and wealth Irish social and political attitudes. Liverpool: Liverpool University Press.

Harvey, B. (2014). Government funding and social justice advocacy. Dublin: The Advocacy Initiative.

Hay, C. (2004). Ideas, interests and institutions in the comparative economy of great transformations. Review of International Political Economy, 11(1), 204-226.

Hearne, R. (2013a). Creating utopia through real struggle: A case study of Dolphin the Rialto community housing campaign; a symbiotic strategy for transformation. Irish Journal of Sociology, 21 (2), 131-144.

Hearne, R. (2013b). No revolution please we are Irish. Village Magazine, October 3, 2014.

Hearne, R. (2015). The Irish Water War, an analysis of participant opinions, social and political impacts and transformative potential of the Irish anti water charges movement. Maynooth: NIRSA.

Heise, A., \& Leirse, H. (2011). The effects of European Austerity Programmes on social security systems. Modern Economy, 2, 498-513.

Hourican, N. (2015, February 28). Role of community is key to understanding Irish water. Irish Times, p. 15.

Howell, J. (2011). Commentary: Crises, opportunities and the elephant in the room. Journal of Civil Society, 7(3), 265-271.

Inclusion Ireland. (2011). Comparing disability allowance to jobseekers shows lack of government understanding of needs of people with disabilities. Retrieved from http://www.inclusionireland. $\mathrm{ie} /$ content/media/68/comparing-disability-allowance-jobseekers-shows-lack-governmentunderstanding-needs 
Irish Independent. (2011). National Women's Council and child benefit protest group PACUB. Retrieved from http://www.independent.ie/videos/irish-news/national-womens-council-andchild-benefits-protest-group-pacub-28942655.html

Irish Times. (2012). 'Sceptical' protesters maintain vigil despite last-minute reversal of cuts. Retrieved from http://www.irishtimes.com/newspaper/ireland/2012/0905/1224323613750.html accessed 28th October 2015

Journal. (2011). Government may reconsider budget cuts to disability allowance. Retrieved from http://www.thejournal.ie/government-may-reconsider-budget-cut-to-disability-allowance298827-Dec2011

Keane, C., et al., (2015). Distributional impact of tax, welfare and public service pay policies: Budget 2015 and budgets 2009-2015. Dublin: ESRI.

Kirby, P., \& Murphy, M. P. (2011). Towards a second republic: Irish politics after the celtic tiger. London: Pluto Press.

Larragy, J. (2014). Asymmetric engagement: The community and voluntary pillar in Irish social partnership. Manchester: Manchester University Press.

Mahoney, J., \& Thelen, K. (2010). Explaining institutional change: Ambiguity, agency, and power. Cambridge: Cambridge University Press.

Mair, P. (2010, July). Paradoxes of Irish democracy (Paper to McGill Summer School Reforming the Republic).

McCabe, C. (2013). Transforming capitalism through real utopias: A critical engagement. Irish Journal of Sociology, 21(2), 51-61.

McCarthy, C. (2009). Report of the special group on public service numbers and expenditure programmes Vols $l$ and 2 July 2009. Dublin: Government Publications.

McCarthy, J. (2014, October 16). Water charge protest large turnout 2014. Sunday Times.

Murphy, M. P. (2012). Irish civil society in the shadow of the Irish state. In Irish Journal of Sociology, 19(2), 173-189.

National Economic and Social Council. (2013). The social dimensions of the crisis: The evidence and its implications (Report No. 134). Retrieved May 14, 2013, from www.nesc.ie

National Women's Council of Ireland. (2009a). 'All our children' briefing paper. Dublin: NWCI.

National Women's Council of Ireland. (2009b). 1 million reasons to oppose cuts in CB. Press statement 26/11/09.

O’Brien, D. (2011, February 19). Searching for the source of perpetual passivity. Irish Times, p. 15.

OPEN. (2012). Seven is too young. Dublin: OPEN. Retrived from http://www.svp.ie/Files/ Documents/SEVEN-IS-TOO-YOUNG!.aspx

Preston, P., \& Silke, H. (2011). Market 'realities': Decoding the ideology and discourses of neo-liberalism. Australian Journal of Communications, 32(2), 1-20.

Roginsky, S., \& Shortall, S. (2009). Civil society as a contested field of meanings. International Journal of Sociology and Social Policy, 29(9/10), 473-487.

Roseneil, S., \& Williams, F. (2004). Introduction to special issue. Social Politics, 11(2), 147-153.

Scholte, J. (2011). Commentary: The show is still running. Journal of Civil Society, 7(3), 277-282.

Urry, J. (2000). Sociology beyond societies. London: Routledge.

Walby, S. (2011). The future of feminism. Cambridge: Polity Press.

Watson, D., \& Maître, B. (2013). Social transfers and poverty alleviation in Ireland: An analysis of the CSO Survey on Income and Living Conditions 2004-2011 (Social Inclusion Report No. 4). Dublin: DSP and ESRI.

White, R. J., \&Wood, P. (in press). Protest and activism with (out) organisation. International Journal of Sociology and Social Policy. Special Edition.

Whitfield, D. (2012). In place of austerity: Restructuring the economy, state and public services. Nottingham: Spokesman.

Wright, E. O. (2013). Transforming capitalism through real utopias. American Sociological Review, $78(1), 1-25$. 